\title{
Evaluation of the anti-inflammatory effects of surface-reaction-type pre-reacted glass-ionomer filler containing root canal sealer in lipopolysaccharide-stimulated RAW264.7 macrophages
}

\author{
Htoo Shwe Sin THEIN ${ }^{1,2}$, Kentaro HASHIMOTO ${ }^{1}$, Nobuyuki KAWASHIMA ${ }^{1}$, Sonoko NODA ${ }^{1}$ and Takashi OKIJI ${ }^{1}$ \\ ${ }^{1}$ Department of Pulp Biology and Endodontics, Division of Oral Health Sciences, Graduate School of Medical and Dental Sciences, Tokyo Medical \\ and Dental University, 1-5-45 Yushima, Bunkyo-ku, Tokyo 113-8549, Japan \\ ${ }^{2}$ Department of Paediatric Dentistry, University of Dental Medicine Mandalay, 62nd Street, Chan Mya Thazi, 05041 Mandalay, Myanmar \\ Corresponding author, Kentaro HASHIMOTO; E-mail: k.hashimoto.endo@tmd.ac.jp
}

\begin{abstract}
A prototype surface-reaction-type pre-reacted glass-ionomer (S-PRG) filler containing root canal sealer (S-PRG sealer) exhibits bioactive potential by releasing multiple ions. This study explored the suppressive effects and modes of action of S-PRG sealer extracts on proinflammatory cytokine expression in lipopolysaccharide (LPS)-stimulated RAW264.7 cells. Expression of proinflammatory cytokines was evaluated by RT-qPCR and ELISA. Expression of phosphorylated nuclear factor-kappa B (p-NF-kB) p65 was evaluated by western blotting. S-PRG sealer extracts significantly downregulated mRNA expression levels of interleukin (IL)-1 $\alpha$, IL-6, and TNF- $\alpha$ in LPS-stimulated RAW264.7 cells; the extracts also reduced the levels of IL-6 protein and p-NF-kB. In order to verify that Zn ${ }^{2+}$ was responsible for downregulation of proinflammatory cytokine expression, N,N,N',N'-tetrakis(2-pyridylmethyl) ethylenediamine (TPEN) was used as a heavy metal chelator with strong affinity for $\mathrm{Zn}^{2+}$. These effects were mitigated by TPEN. The application of $\mathrm{ZnCl}_{2}$ reproduced the actions of S-PRG sealer extracts. These data suggest that S-PRG sealer has anti-inflammatory potential involving heavy metal ions such as $\mathrm{Zn}^{2+}$.
\end{abstract}

Keywords: S-PRG filler, Endodontic sealer, Inflammatory cytokine, NF-kB pathway, Zinc ion

\section{INTRODUCTION}

The ultimate objectives of root canal treatment are the complete eradication of bacterial infection from the root canal system and the prevention of bacterial invasion into the periradicular tissues ${ }^{1}$. Thus, following thorough cleaning and shaping, the root canal space is hermetically sealed, most often with endodontic sealers and core materials. Thus far, several classes of endodontic sealers have been developed, including sealers based on zinc oxide eugenol, calcium hydroxide, glass ionomer, epoxy resin, methacrylate resin, and calcium silicate ${ }^{1,2)}$. These materials must meet several physical requirements including high sealing ability and low solubility to establish a long-lasting seal ${ }^{3-5}$. Moreover, endodontic sealers are usually applied in contact with diseased periradicular tissues; therefore, they should be biocompatible and offer beneficial biological actions, such as anti-inflammatory $\left.{ }^{6}\right)$ and proregenerative effects ${ }^{7}$. However, no available materials are considered ideal ${ }^{1)}$, and thus there is a need for the development of new materials with improved physical and/or biological properties.

Surface reaction-type pre-reacted glass ionomer (S-PRG) fillers comprise a class of bioactive filler materials that are produced by an acid-base reaction of porous silica glass-coated fluoroboroaluminosilicate glass fillers with a polycarboxylic acid solution ${ }^{8)}$. S-PRG fillers release several ions (e.g., boron, aluminum, silicon, sodium, strontium, and fluoride) that confer these fillers with properties including anti-demineralizing-11), remineralizing ${ }^{12)}$, and anti-microbial abilities ${ }^{13,14)}$. Thus,
S-PRG fillers have been incorporated into various dental materials such as resin composites ${ }^{13)}$, coating resins ${ }^{9)}$, and dental sealants ${ }^{10)}$.

A prototype S-PRG filler containing root canal sealer (S-PRG sealer) has been developed to incorporate the bioactive properties of S-PRG fillers into an endodontic sealer ${ }^{15}$; it also releases multiple ions (boron, aluminum, silicon, sodium, zinc, strontium, and fluoride) ${ }^{16)}$. The S-PRG sealer is presumed to favor osteoblastic differentiation because extracts from the S-PRG sealer induce osteoblastic differentiation and mineralization of Kusa-A1, an osteoblastic cell line, through the calciumsensing receptor-induced activation of extracellular signal-regulated kinase and p38 mitogen-activated protein kinase ${ }^{16)}$. Anti-inflammatory properties of the S-PRG sealer have also been described in a recent study: subcutaneous implantation of set S-PRG sealer led to reduced macrophage infiltration, compared with a silica filler-containing (non-SPRG filler-containing) sealer ${ }^{17}$. However, these results could be largely attributed to the difference in biocompatibility between the two materials, and thus anti-inflammatory effects of the S-PRG sealer have not yet been fully evaluated.

This study was performed to obtain insights regarding the anti-inflammatory functions of the S-PRG sealer. We used macrophages as the target cell type because they are the predominant immunocompetent cells throughout the development of periapical lesions ${ }^{18,19)}$. Moreover, they produce many proinflammatory and boneresorbing cytokines that are involved in the process of active lesion expansion ${ }^{20,21}$. Thus, the specific aim of this study was to explore the suppressive effects and modes 
of action of S-PRG sealer extracts on proinflammatory cytokine expression in lipopolysaccharide (LPS)stimulated RAW264.7 mouse macrophages ${ }^{22)}$. The null hypothesis was that S-PRG sealer extracts would have no effect on proinflammatory cytokine expression in LPS-stimulated RAW264.7 cells.

\section{MATERIALS AND METHODS}

Cell culture and chemicals

RAW264.7 mouse macrophages ${ }^{22)}$ around passage 20 (Riken Bioresource Research Center, Tsukuba, Japan) were cultured in Dulbecco's modified Eagle's medium (DMEM; FUJIFILM Wako Pure Chemical, Osaka, Japan) containing heat-inactivated $\left(56^{\circ} \mathrm{C}\right.$ for $\left.30 \mathrm{~min}\right)$ $10 \%$ fetal bovine serum (FBS; HyClone/GE Healthcare, Chicago, IL, USA) and $1 \%$ antibiotics (penicillinstreptomycin-amphotericin B suspension; FUJIFILM Wako Pure Chemical) at $37^{\circ} \mathrm{C}$ in $5 \% \mathrm{CO}_{2}$ with $100 \%$ humidity. Cells were then subcultured carefully before they reached confluence. LPS (Escherichia coli O111: B4; Sigma-Aldrich, St. Louis, MO, USA; $100 \mathrm{ng} / \mathrm{mL}$ ) was used to induce the expression of inflammatory cytokines and NF-kB signaling in RAW264.7 cells. N,N,N',N'tetrakis(2-pyridylmethyl)ethylenediamine (TPEN; 50 $\mu \mathrm{M}$, Dojindo, Kumamoto, Japan) is a chelator ${ }^{23)}$ with strong affinities for $\mathrm{Zn}^{2+}, \mathrm{Fe}^{2+}$, and $\mathrm{Mn}^{2+}$ and low affinity for $\mathrm{Ca}^{2+}$. TPEN was used to eliminate heavy metal ions. Other chemicals used in this study were as follows; $\mathrm{B}(\mathrm{OH})_{3}(300 \mu \mathrm{g} / \mathrm{mL}), \mathrm{SrCl}_{2}(15 \mu \mathrm{g} / \mathrm{mL}), \mathrm{NaF}(45 \mu \mathrm{g} / \mathrm{mL})$, and $\mathrm{ZnCl}_{2}(20 \mu \mathrm{g} / \mathrm{mL})$ (FUJIFILM Wako Pure Chemical). The concentrations of these solutions were determined based on the concentrations of corresponding ions released from S-PRG sealer extracts ${ }^{16)}$.

\section{Preparation of sealer extracts}

S-PRG sealer (Shofu, Kyoto, Japan) and Canals N (CN; a zinc oxide-non-eugenol sealer, Showa Yakuhin Kano, Tokyo, Japan) were used in this study. The compositions of the root canal sealers are described in Table 1. The sealers were mixed in accordance with the manufacturer's instructions under aseptic conditions and used to fill sterile polypropylene discs $(8 \mathrm{~mm}$ diameter, $3 \mathrm{~mm}$ height). S-PRG sealer and CN were allowed to set for respective durations of $72 \mathrm{~h}$ and $24 \mathrm{~h}$, both at $37^{\circ} \mathrm{C}$ and $100 \%$ humidity. Set samples were placed in DMEM $(10 \mathrm{~mL})$, then shaken at room temperature for $24 \mathrm{~h}$ and sterilized through a membrane filter $(0.45 \mu \mathrm{m}$ pore size, Sartorius, Göttingen, Germany).

\section{Cell viability assay}

RAW264.7 cells ( $3 \times 10^{3}$ cells/well, $100 \mu \mathrm{L}, 96$-well plate) were cultured for 24,48 , and $72 \mathrm{~h}$ in the presence or absence (control) of S-PRG sealer extracts. Cell viability was measured using a WST-8 assay (CCK-8, Dojindo). Briefly, $10 \mu \mathrm{L}$ of CCK- 8 solution was added to each well of a 96-well plate, then incubated for $1 \mathrm{~h}$; the optical density of each well at $450 \mathrm{~nm}$ (OD450) was measured using a microplate reader (Sunrise, Tecan, Männedorf, Switzerland).

Reverse transcription-quantitative polymerase chain reaction

RAW264.7 cells $\left(2 \times 10^{5}\right.$ cells/well, 12 -well plate) were cultured in DMEM without FBS for $24 \mathrm{~h}$, then cultured with samples for $3 \mathrm{~h}$. Total RNAs were extracted at 3 $\mathrm{h}$ after application of the samples with a QuickGeneMini80 kit (Kurabo Biomedical, Osaka, Japan). The isolated RNA (150 ng) was reverse transcribed to cDNA by reverse transcriptase (PrimeScript ${ }^{\mathrm{TM}} \mathrm{RT}$ Reagent

Table 1 Root canal sealers used in this study

\begin{tabular}{clc}
\hline Product & \multicolumn{1}{c}{ Composition } & Lot No. \\
\hline \multirow{2}{*}{ S-PRG sealer } & Powder: Zinc oxide-based inorganic compound filler, S-PRG filler, additive & 140901P \\
& Liquid: Polycarboxylic acid sodium salt, water, other & 121301L \\
& Powder: Zinc oxide, bismuth subcarbonate & $9006 \mathrm{UA}$ \\
Canals N & Liquid: Fatty acids, propylene glycol & $9007 \mathrm{UA}$ \\
\hline
\end{tabular}

Table 2 Primer sequences

\begin{tabular}{lllll}
\hline \multicolumn{1}{c}{ Genes } & \multicolumn{1}{c}{ Forward Primers (5'-3') } & \multicolumn{1}{c}{ Reverse Primers (5'-3') } & Accession No. & $\begin{array}{c}\text { Size } \\
(\mathrm{bp})\end{array}$ \\
\hline$\beta$-actin & GTAAAGACCTCTATGCCAACACAGT & AATGATCTTGATCTTCATGGTGCTA & NM_007393 & 122 \\
IL-1 $\alpha$ & ATTTAACCAAGTGGTGCTGAGATAG & CACCTTACACCTACCAGAGTGATTT & NM_010554 & 137 \\
IL-6 & TCTGGCTTTGTCTTTCTTGTTATCT & TGGATGCTACCAAACTGGATATAAT & NM_031168 & 130 \\
TNF $\alpha$ & ATCATCTTCTCAAAATTCGAGTGAC & CTAGTTGGTTGTCTTTGAGATCCAT & NM_013693 & 235 \\
PPAR $\alpha$ & GCCTGTCTGTCGGGATGT & GGCTTCGTGGATTCTCTTG & NM_001113418 & 216 \\
IL-10 & GATCATCATGTATGCTTCTATGCAG & GATTTCTCCCCTGTGAAAATAAGAG & NM_010548 & 140 \\
\hline
\end{tabular}


Kit, Takara Bio, Kusatsu, Japan). Real-time polymerase chain reaction (PCR) analysis was performed with cDNA, primers, and Taq polymerase (GoTaq qPCR Master Mix, Promega, Madison, WI, USA) using a realtime PCR detection system (CFX96; Bio-Rad, Hercules, CA, USA). Specific primers were used to detect mRNAs for interleukin (IL)-1 $\alpha$, IL-6, tumor necrosis factor (TNF) $\alpha$, peroxisome proliferator-activated receptor (PPAR) $\alpha$, and IL-10 (Table 2). Beta-actin was used as an internal control. Relative gene expression values were calculated with $\Delta \Delta \mathrm{CT}$-based fold-change calculations.

\section{Western blotting}

RAW264.7 cells $\left(1 \times 10^{5}\right.$ cells/well, 24-well plate) were cultured in DMEM without FBS for $24 \mathrm{~h}$, then cultured with samples for $10 \mathrm{~min}$. Cells were then lysed in $100 \mu \mathrm{L}$ of a radioimmunoprecipitation assay buffer containing proteinase and phosphatase inhibitors (cOmplete and PhosSTOP; Sigma-Aldrich). Lysates were loaded into ready-to-use sodium dodecyl sulfate-polyacrylamide gels (e-Pagel; ATTO, Tokyo, Japan) and subjected to electrophoresis; separated proteins in the gels were transferred to polyvinylidene difluoride membranes (GE Healthcare) using a semi-dry transfer system (0.15 mA, 1 h; WSE-4040, ATTO). Membranes were then incubated at $4^{\circ} \mathrm{C}$ overnight with the following primary antibodies: rabbit anti-nuclear factor-kappa B (NFkB) p65 (\#8242, 1:1000, Cell Signaling Technology, Danvers, MA, USA), rabbit anti-phospho-NF-kB p65 (\#3033, 1:1000, Cell Signaling Technology), and a horseradish peroxidase-conjugated rabbit anti-alpha tubulin (PM054-7, 1:4000; MBL, Nagoya, Japan). After membranes had been washed with Tris-buffered saline containing Tween $20(1 \% \mathrm{v} / \mathrm{v})$, they were incubated at room temperature for $1 \mathrm{~h}$ with a horseradish peroxidaselabeled antirabbit IgG secondary antibody (\#1706515, 1:5000, Bio-Rad). Horseradish peroxidase substrate (Immobilon, Merck Millipore, Burlington, MA, USA) was applied as a chemiluminescent reagent, and the developed membranes were imaged using the LAS3000 Mini Imaging System (Fuji Film/GE Healthcare, Tokyo, Japan). The corresponding bands were measured with ImageJ software (National Institutes of Health, Bethesda, MD, USA) and their ratios were calculated.

Enzyme-linked immunosorbent assay (ELISA) analysis RAW264.7 cells $\left(1 \times 10^{5}\right.$ cells/well, 12 -well plate) were cultured in DMEM without FBS for $24 \mathrm{~h}$, then cultured with samples for $24 \mathrm{~h}$. Synthesis of IL-6 in the medium was measured with an ELISA kit (IL-6 Duo Set, R\&D Systems, Minneapolis, MN, USA), in accordance with the manufacturer's protocol. 3,3',5,5'-tetramethylbenzidine (SureBlue TMB Microwell Peroxidase Substrate, KPL, Milford, MA, USA) was used as a chromogenic substrate, and $0.6 \mathrm{~N}$ sulfuric acid was used as a stop solution. Color change was measured with a microplate reader (wavelength: $450 \mathrm{~nm}$, Sunrise, Tecan) and the protein concentrations were calculated using a standard curve.

\section{Statistical analysis}

Results are shown as means \pm standard deviations. Oneway analysis of variance (ANOVA) followed by the Tukey-Kramer or Dunnett's test was used for multiple comparisons; the F-test followed by Student's $t$-test was used for comparisons of two groups. Statistical analyses were performed using Prism software version 6 (GraphPad, San Diego, CA, USA). Differences with $p<0.05$ were considered statistically significant.

\section{RESULTS}

First, we examined the effects of S-PRG sealer extract on RAW264.7 cell growth. In the presence of twofold diluted S-PRG sealer extract, cell growth was significantly depressed at 24, 48, and $72 \mathrm{~h}$, compared with control (no

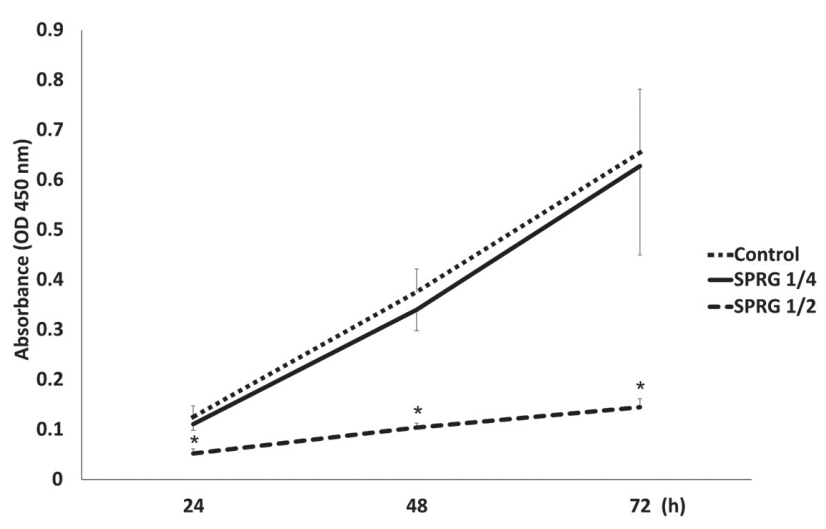

Fig. 1 Effects of S-PRG sealer extract on viability of RAW264.7 cells.

The viability of RAW264.7 cells was evaluated in the presence of various dilutions of S-PRG sealer extract at $24 \mathrm{~h}, 48 \mathrm{~h}$, and $72 \mathrm{~h}$. SPRG 1/2: twofold diluted S-PRG sealer extract, SPRG 1/4: fourfold diluted S-PRG sealer extract, $n=4,{ }^{*} p<0.05$.
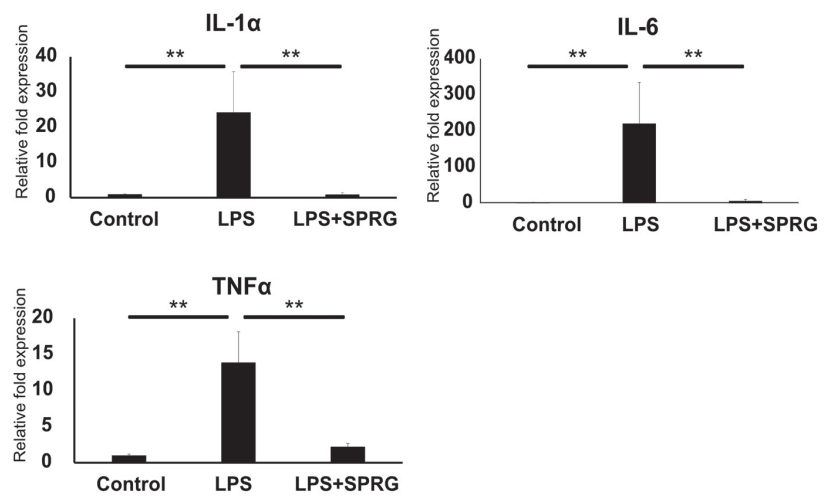

Fig. 2 Effects of S-PRG sealer extract on IL-1 $\alpha$, IL-6, and $\mathrm{TNF} \alpha$ mRNA expression levels in LPS-stimulated RAW264.7 cells.

mRNA expression levels in LPS-stimulated RAW264.7 cells were determined at $3 \mathrm{~h}$ after the addition of S-PRG sealer extract. SPRG: fourfold diluted S-PRG sealer extract, $n=3,{ }^{* *} p<0.01$. 
sealer extract) and fourfold diluted S-PRG sealer extract $(p<0.05$, Fig. 1). However, cell growth in the presence of fourfold diluted S-PRG sealer extract was generally similar to growth in the control condition (Fig. 1).

Next, we investigated the effect of S-PRG sealer
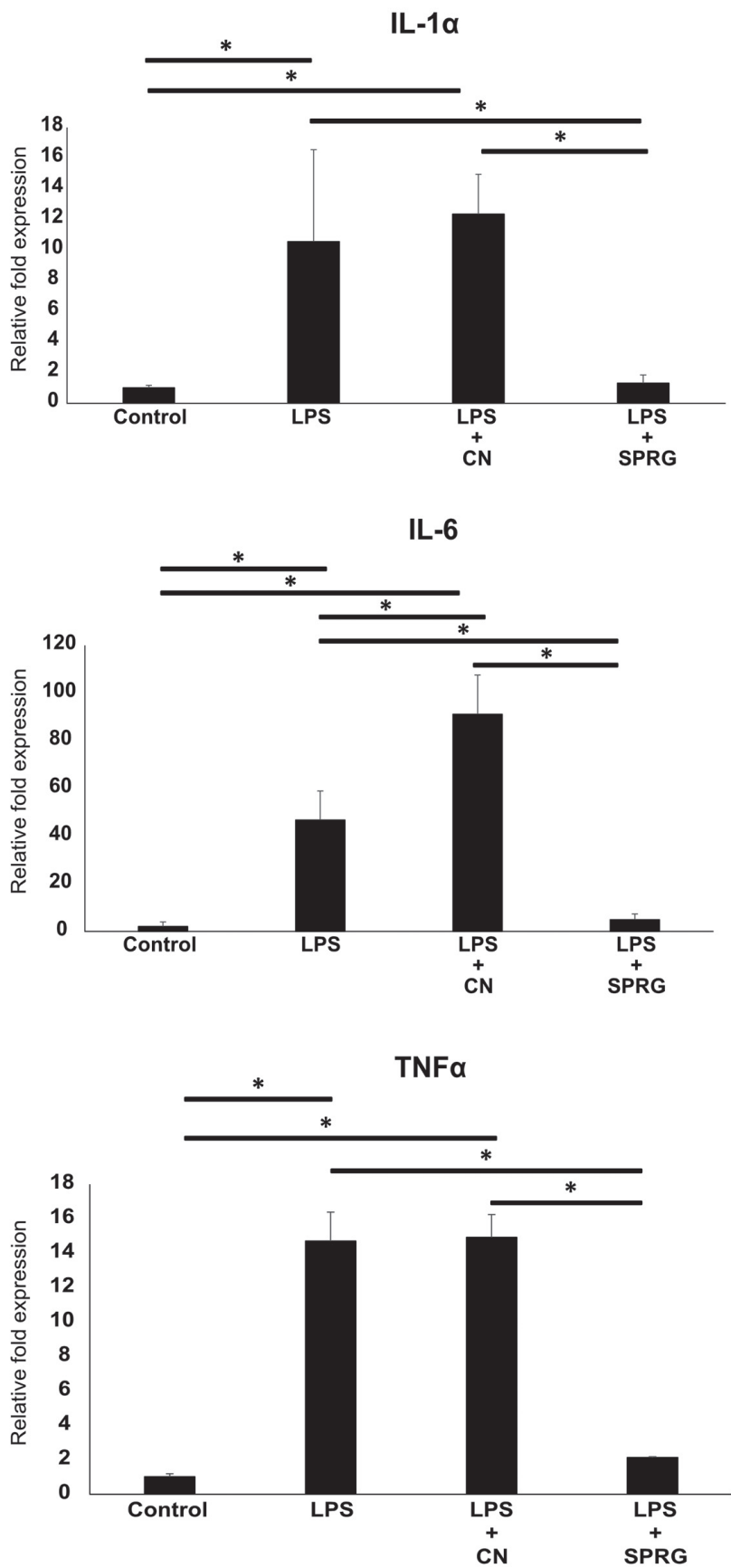

Fig. 3 Effects of Canals N (CN) extracts on IL- $1 \alpha$, IL-6, and $\mathrm{TNF} \alpha \mathrm{mRNA}$ expression levels in LPS-stimulated RAW264.7 cells.

mRNA expression levels were determined at $3 \mathrm{~h}$ after the addition of CN or S-PRG sealer extracts. CN: Canals N extract, SPRG: fourfold diluted S-PRG sealer extract, $n=3,{ }^{*} p<0.05$. extract on proinflammatory cytokine expression in LPS-stimulated RAW264.7. As shown in Fig. 2, LPS treatment upregulated the mRNA expression levels of IL-1 $\alpha$, IL-6, and TNF $\alpha$ in RAW264.7 cells; these expression levels were significantly downregulated by the application of fourfold diluted S-PRG sealer extract $(p<0.01$, Fig. 2). As shown in Fig. 3, extracts from $\mathrm{CN}$ failed to show a reducing effect on LPS-induced

IL-1 $\alpha$

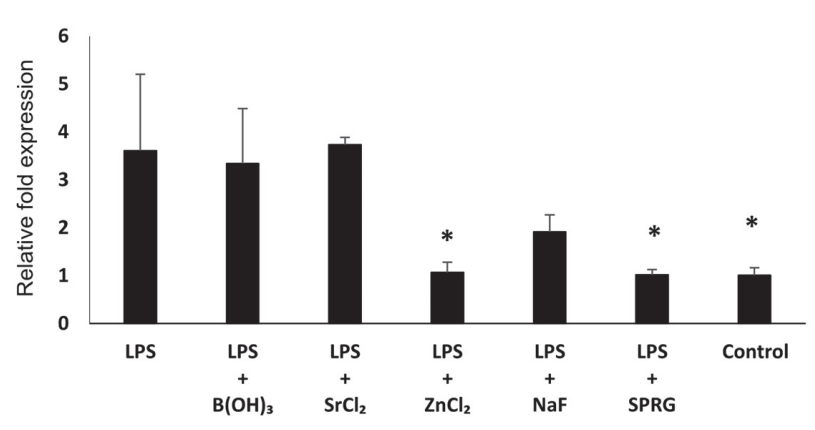

IL-6

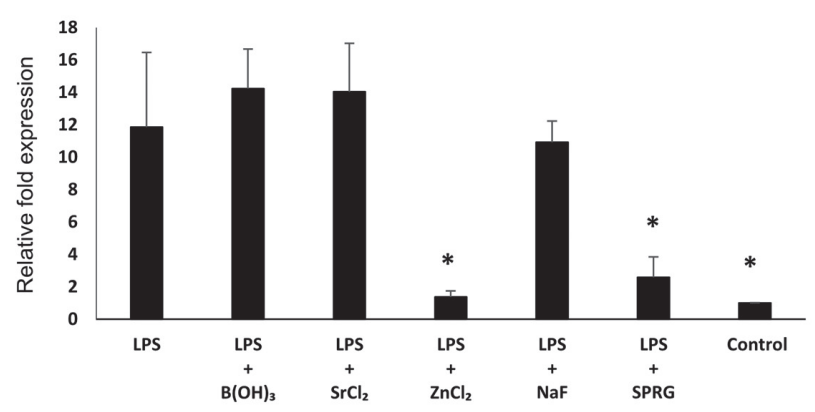

TNFa

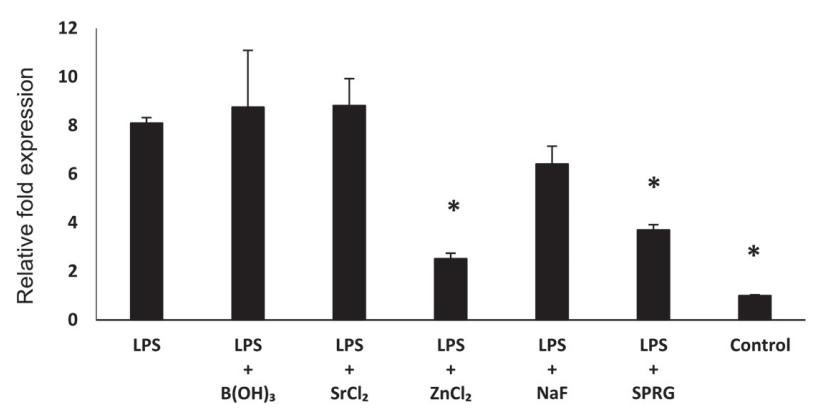

Fig. 4 Effects of $\mathrm{B}(\mathrm{OH})_{3}, \mathrm{SrCl}_{2}, \mathrm{ZnCl}_{2}, \mathrm{NaF}$, and S-PRG sealer extract on IL- $1 \alpha$, IL- 6 , and TNF $\alpha$ mRNA expression levels in LPS-stimulated RAW264.7 cells.

mRNA expression levels were determined at $3 \mathrm{~h}$ after the addition of $\mathrm{B}(\mathrm{OH})_{3}, \mathrm{SrCl}_{2}, \mathrm{ZnCl}_{2}, \mathrm{NaF}$, and S-PRG sealer extract. SPRG: fourfold diluted S-PRG sealer extract, $n=3,{ }^{*} p<0.05$ versus LPS. 
upregulation of IL-1 $\alpha$, IL-6, and TNF $\alpha$ mRNA expression levels in RAW264.7 cells.

S-PRG sealer extract contains various ions released from the sealer ${ }^{16)}$. Therefore, we examined whether the cytokine mRNA downregulation by sealer extract in LPS-stimulated RAW264.7 cells could be reproduced by $\mathrm{B}(\mathrm{OH})_{3}, \quad \mathrm{SrCl}_{2}, \quad \mathrm{ZnCl}_{2}, \quad$ and $\mathrm{NaF}$ solutions. The concentrations of the corresponding ions in these solutions were adjusted to the levels present in the fourfold diluted S-PRG sealer extract. $\mathrm{ZnCl}_{2}$ significantly downregulated the IL- $1 \alpha$, IL-6, and TNF $\alpha$ mRNA expression in RAW264.7 cells, compared with the levels in LPS-stimulated RAW264.7 cells $(p<0.05$, Fig. 4). In contrast, $\mathrm{B}(\mathrm{OH})_{3}, \mathrm{SrCl}_{2}$, and $\mathrm{NaF}$ solutions
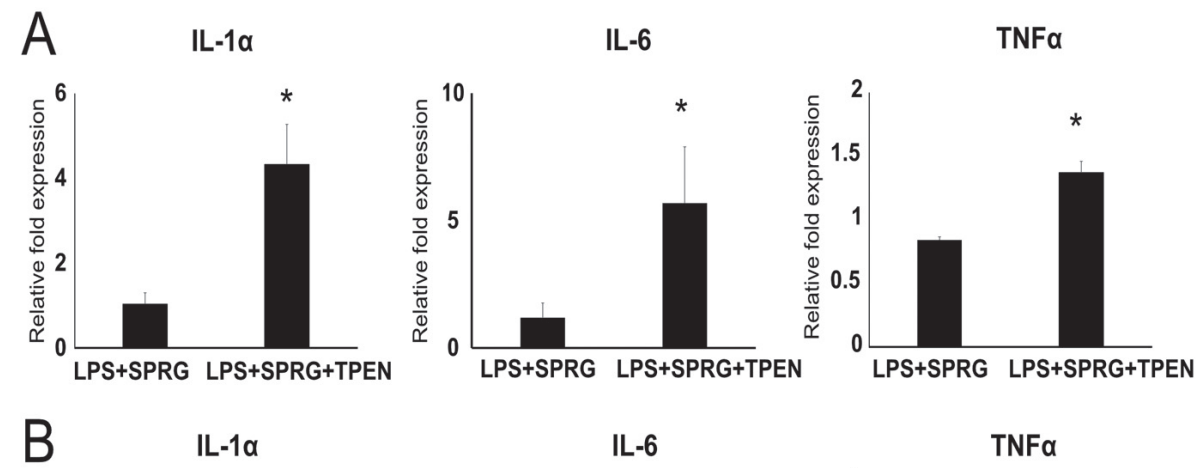

IL-6
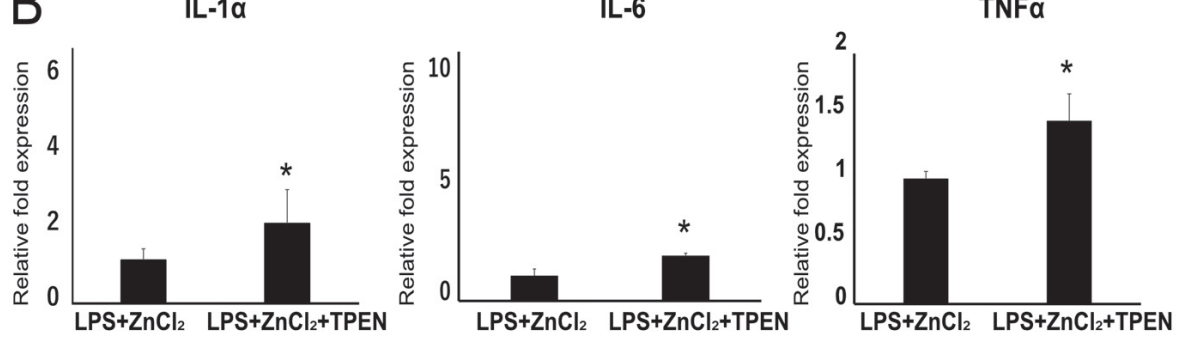

Fig. 5 Effects of TPEN on IL-1 $\alpha$, IL-6, and TNF $\alpha$ mRNA expression levels in LPSstimulated RAW264.7 cells in the presence of S-PRG sealer extract and $\mathrm{ZnCl}_{2}$. mRNA expression levels were determined at $3 \mathrm{~h}$ after the addition of S-PRG sealer extract (A) and $\mathrm{ZnCl}_{2}(\mathrm{~B})$, together with TPEN. SPRG: fourfold diluted S-PRG sealer extract, $n=3,{ }^{*} p<0.05$.

A

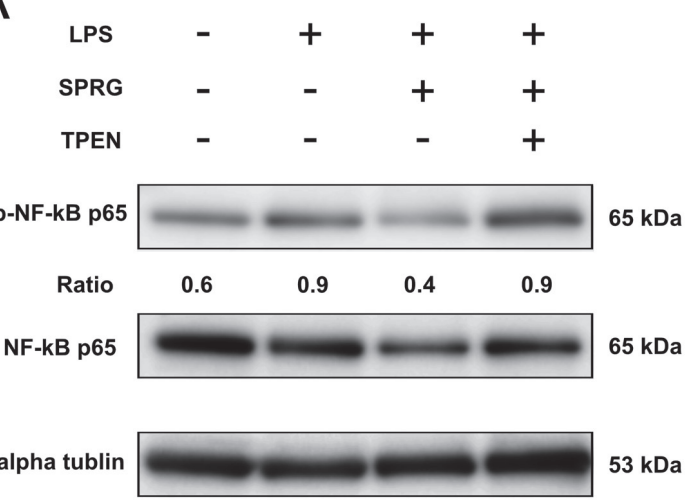

B

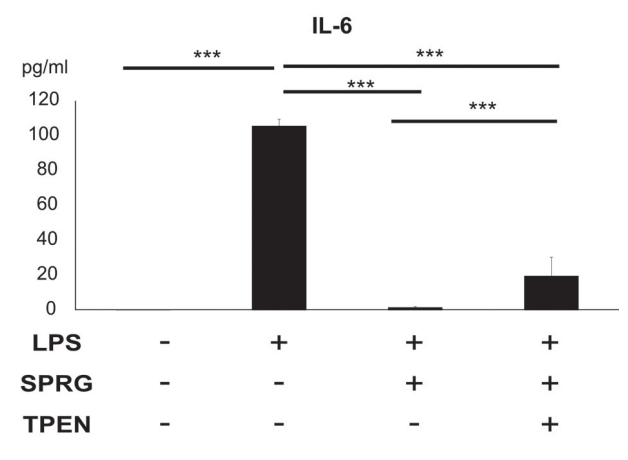

Fig. 6 Effects of S-PRG sealer extract and TPEN on NF-kB signaling and IL-6 expression in LPSstimulated RAW264.7 cells.

(A) Expression levels of p-NF-kB, NF-kB, and alpha tubulin (control) in LPS-stimulated RAW264.7 cells in the presence of S-PRG sealer extract and TPEN were evaluated by western blotting, and the intensities of bands were measured by ImageJ software. SPRG: fourfold diluted S-PRG sealer extract. All experiments were performed three times and representative results are shown. (B) Expression levels of IL-6 in LPS-stimulated RAW264.7 cells in the presence of S-PRG sealer extract and TPEN were evaluated by ELISA. SPRG: fourfold diluted S-PRG sealer extract, Ratio: the ratio of pixel intensity of $\mathrm{p}-\mathrm{NF}-\mathrm{kB}$ versus NF-kB. $n=3,{ }^{* * *} p<0.001$. 

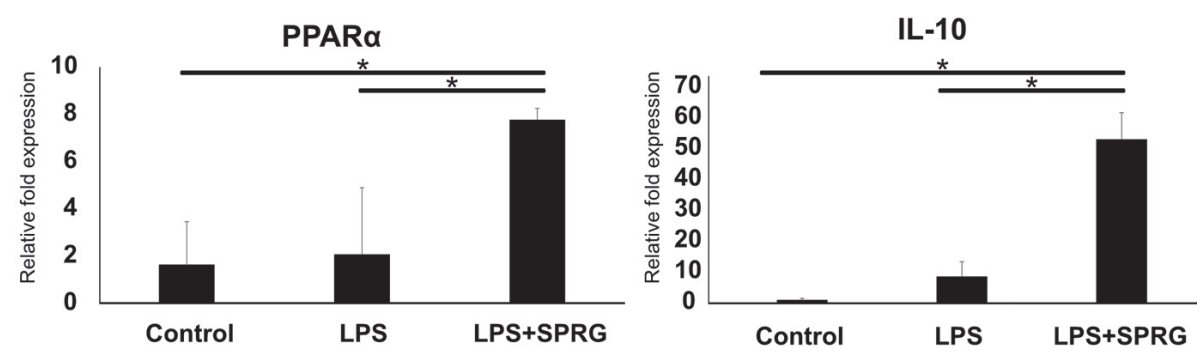

Fig. 7 Effects of S-PRG sealer extract on PPAR $\alpha$ and IL-10 mRNA expression levels in LPS-stimulated RAW264.7 cells.

mRNA expression levels were determined at $3 \mathrm{~h}$ after the addition of S-PRG sealer extract. SPRG: fourfold diluted S-PRG sealer extract, $n=3,{ }^{*} p<0.05$.

failed to inhibit the increased expression levels of proinflammatory cytokines (Fig. 4).

We then sought to verify whether $\mathrm{Zn}^{2+}$ was responsible for the cytokine downregulation caused by S-PRG sealer extract. TPEN, a heavy metal chelator ${ }^{23)}$ with a strong affinity for $\mathrm{Zn}^{2+}$, was added to the sealer extract to remove the $\mathrm{Zn}^{2+}$ activity. As shown in Fig. 5, TPEN mitigated the reducing effects of S-PRG sealer extract and $\mathrm{ZnCl}_{2}$ solution $(p<0.05)$.

We next examined the effects of S-PRG sealer extracts on NF-kB signaling and on IL-6 protein synthesis in LPS-stimulated RAW264.7 cells. NF$\mathrm{kB}$ signaling is a major signaling cascade involved in LPS-induced proinflammatory cytokine synthesis ${ }^{24)}$. As shown in Fig. 6A, phosphorylation of NF-kB promoted by LPS stimulation was downregulated by treatment with fourfold diluted S-PRG sealer extract. LPSstimulated IL-6 protein synthesis from RAW264.7 cells was significantly downregulated by treatment with fourfold diluted S-PRG sealer extract ( $p<0.001$; Fig. 6B). Moreover, TPEN partially abolished the reducing effects of the sealer extract on both NF-kB phosphorylation (Fig. 6A) and IL-6 protein synthesis $(p<0.001$, Fig. $6 \mathrm{~B})$ in LPS-stimulated RAW264.7 cells.

We also examined the effects of S-PRG sealer extract on the mRNA expression of PPAR $\alpha$ and IL10 in LPS-stimulated RAW264.7 cells. PPAR $\alpha$ is a nuclear transcription factor known to downregulate proinflammatory cytokine expression ${ }^{25,26)}$, and IL-10 is a typical anti-inflammatory cytokine ${ }^{27)}$. The mRNA expression levels of PPAR $\alpha$ and IL-10 did not differ between control and LPS-stimulated RAW264.7 cells, whereas LPS stimulation in the presence of S-PRG sealer extracts induced significant increases in the mRNA expression levels of PPAR $\alpha$ and IL-10 $(p<0.05$, Fig. 7).

\section{DISCUSSION}

In this study, we focused on whether and how the S-PRG sealer extract influences proinflammatory cytokine expression in LPS-stimulated RAW264.7 cells. The main findings were that S-PRG sealer extract induced the downregulation of IL- $1 \alpha$, IL- 6 , and TNF $\alpha$ mRNA expression levels; the extract also reduced IL- 6 protein levels. These downregulation effects were partially abolished by the addition of TPEN and mimicked by the addition of $\mathrm{ZnCl}_{2}$ (instead of the sealer extract). Thus, the findings led to rejection of the null hypothesis that S-PRG sealer extracts would have no effect on proinflammatory cytokine expression in LPS-stimulated RAW264.7 cells. Our findings indicate that the cytokine reducing action of S-PRG sealer extract is greatly dependent on $\mathrm{Zn}^{2+}$ released from the sealer; however, other mechanisms (e.g., pathways dependent on PPAR $\alpha$ and IL-10) may have some roles as alternative antiinflammatory mechanisms.

Although fourfold diluted S-PRG sealer extract showed minimal cytotoxicity in RAW264.7 cells, twofold diluted extract showed significant cytotoxicity (Fig. 1). This is consistent with the finding that undiluted S-PRG filler eluate caused cell death in human gingival fibroblasts, presumably through releasing $\mathrm{BO}_{3}{ }^{3-}, \mathrm{Sr}^{2+}$, and $\mathrm{F}^{-}$in high concentrations ${ }^{28)}$. Moreover, S-PRG sealer contains polycarboxylic acid in the liquid component, which could have contributed to the slight cytotoxicity of this sealer ${ }^{29)}$.

LPS is involved in the pathogenesis of periapical lesions through the induction of proinflammatory cytokines from activated macrophages ${ }^{30)}$. Proinflammatory cytokines (e.g., IL-1 $\alpha$, IL-6, and $\mathrm{TNF} \alpha$ ) induce osteoclastogenesis and osteoclastic bone resorption, both of which are involved in periapical alveolar bone destruction ${ }^{21)}$. This study revealed that S-PRG sealer extracts downregulated the proinflammatory cytokine expression in LPS-stimulated RAW264.7 cells (Fig. 2). This result implies that S-PRG sealer can partially alleviate periradicular inflammation and bone destruction by negatively controlling proinflammatory activity in macrophages. This is consistent with the finding that a root canal dressing containing S-PRG fillers promoted healing in experimentally induced rat periapical lesions ${ }^{31)}$, potentially because S-PRG fillers cause downregulation of proinflammatory cytokines.

To reveal the mechanisms underlying the antiinflammatory action of S-PRG sealer extract, we focused on the involvement of various ions that are released 
from S-PRG sealer ${ }^{16)}$. It has been reported that a boroncontaining organic compound reduces the levels of proinflammatory factors (e.g., IL-1 $\beta$ and IL-6) in LPSstimulated RAW264.7 macrophages ${ }^{32}$. $\mathrm{NaF}$ reduces the mRNA expression levels of IL-1 $\beta$, IL-8, and TNF $\alpha$ in IL$1 \beta$-stimulated human gingival fibroblasts ${ }^{33)}$. $\mathrm{SrCl}_{2}$ also significantly inhibits the expression of proinflammatory cytokines (e.g., TNF $\alpha$, IL-1 $\beta$, and IL-6) by downregulation of the NF-kB pathway ${ }^{34)}$. $\mathrm{ZnCl}_{2}$ downregulates the mRNA expression levels of IL-1 $\beta$, IL-6, and IL-8 in immortalized human oral keratinocytes ${ }^{35)}$. In the present study, $\mathrm{B}(\mathrm{OH})_{3}, \mathrm{SrCl}_{2}$ and $\mathrm{NaF}$ (with ion concentrations adjusted to the concentrations in diluted S-PRG) did not reduce the mRNA expression levels of proinflammatory cytokines in LPS-stimulated macrophages. In contrast, $\mathrm{ZnCl}_{2}$ significantly downregulated the mRNA expression levels of IL- $1 \alpha$, IL- 6 , and TNF $\alpha$ (Fig. 4). These findings suggested that $\mathrm{Zn}^{2+}$ has an important role in the antiinflammatory effects of S-PRG sealer. Accordingly, we applied TPEN, a heavy metal chelating agent with high affinity for $\mathrm{Zn}^{2+}$ as an intracellular chelator ${ }^{23,36)}$, which has been widely used ${ }^{37)}$ to investigate the role of $\mathrm{Zn}^{2+}$. As shown in Fig. 5, the inhibitory actions of S-PRG sealer extract and $\mathrm{ZnCl}_{2}$ on the mRNA expression levels of IL$1 \alpha$, IL-6, and TNF $\alpha$ in LPS-stimulated RAW264.7 cells were abrogated by the addition of TPEN. Therefore, our findings implied that heavy metal ions, particularly $\mathrm{Zn}^{2+}$, have important roles in the S-PRG sealer extract-induced suppression of inflammatory cytokines. In addition, application of TPEN to LPS-stimulated RAW264.7 cells induced downregulation of proinflammatory mediator expression (data not shown). This phenomena may be caused by depletion of intra-cellular heavy metal ions, which are essential for normal cell function ${ }^{38)}$. CN, which is a zinc oxide-containing root canal sealer, achieves satisfactory biocompatibility by replacing eugenol with fatty acids from a Grossman sealer ${ }^{39)}$ and releases ${ }^{16)}$ a small amount of $\mathrm{Zn}^{2+}$. However, extracts of $\mathrm{CN}$ failed to downregulate the mRNA expression levels of IL- $1 \alpha$, IL-6, and TNF $\alpha$ (Fig. 3). This is presumably because the concentration of $\mathrm{Zn}^{2+}$ released from set $\mathrm{CN}$ may be insufficient to induce cytokine downregulation.

We also found that $\mathrm{p}-\mathrm{NF}-\mathrm{kB}$ expression was downregulated by S-PRG sealer extract in LPSstimulated RAW264.7 cells (Fig. 6A). This result implies that the reducing action of S-PRG sealer extract involves inhibition of NF-kB signaling, which is a major signal transduction pathway in LPS/Toll-like receptor inflammatory signaling, as well as a key signaling cascade for proinflammatory cytokine expression ${ }^{24}$. This notion is supported by a previous finding that the blockade of NF-kB phosphorylation results in substantial decreases in the expression levels of proinflammatory cytokines in LPS-stimulated RAW264.7 cells $^{40)}$ and dental pulp cell ${ }^{41)}$. NF-kB is also involved in osteoclast differentiation $^{42}$ and the downregulation of NF-kB signaling contributes to osteoclastogenesis inhibition ${ }^{43)}$. Furthermore, S-PRG filler containing root canal dressing reportedly decreases the number of osteoclasts and the degree of inflammatory response in periapical lesions ${ }^{31)}$.
$\mathrm{Zn}^{2+}$ reportedly downregulates the I kappa B kinase- $\alpha$ (IKK- $\alpha$ )/IKK- $\beta / \mathrm{NF}-\kappa \mathrm{B}$ signaling pathway through the induction of A20, a zinc finger protein known to suppress TNF $\alpha$ and IL-1 $\beta^{44)}$. These mechanisms may be involved in the negative regulation of proinflammatory cytokine expression. In contrast, TPEN-induced selective $\mathrm{Zn}^{2+}$ deficiency upregulates NF-kB activation and increases the expression levels of NF-kB controlled vascular endothelial growth factor, IL-6, and IL-8 in prostate cancer cells ${ }^{45)}$; moreover, $\mathrm{Zn}^{2+}$ deficiency enhances the production of proinflammatory cytokines in promyeloid cells ${ }^{46)}$. Furthermore, $\mathrm{Zn}^{2+}$ enhances the expression of PPAR $\alpha^{47)}$, which belongs to the steroid receptor superfamily of nuclear transcription factors ${ }^{48)}$ and acts as a negative regulator of NF-kB signaling and proinflammatory cytokines (e.g., IL- $1 \beta$ and $\mathrm{TNF} \alpha)^{49}$ ). Mechanisms involving PPAR $\alpha$ could be associated with the negative regulation of NF-kB by S-PRG sealer extract, because we found that S-PRG sealer extract induced PPAR $\alpha$ mRNA expression in LPS-stimulated RAW264.7 cells (Fig. 7). Taken together, our findings suggest that the reducing effect of $\mathrm{Zn}^{2+}$ on NF-kB signaling is associated with the S-PRG sealer extractinduced downregulation of proinflammatory cytokines in LPS-stimulated RAW264.7 cells (Fig. 2).

TPEN induced increased IL-6 synthesis in LPSstimulated RAW264.7 cells that were treated with S-PRG sealer extract; however, IL-6 synthesis was much higher in LPS-stimulated RAW264.7 cells that had not been treated with S-PRG sealer extract (Fig. 6B). This finding indicates that additional non- $\mathrm{Zn}^{2+}$-related mechanisms may be present. To address this, we examined IL10 , which is an important endogenous suppressor of infection-stimulated periapical lesions that acts through the inhibition of proinflammatory factors (e.g., IL- $1 \alpha)^{50)}$. We revealed that the S-PRG sealer extract promoted IL10 mRNA expression in LPS-stimulated RAW264.7 cells (Fig. 7). Further studies are necessary to explore the mechanisms governing the anti-inflammatory functions of S-PRG sealer.

Our study revealed that S-PRG sealer extract downregulated the expression of proinflammatory cytokines in macrophages. Such an anti-inflammatory property would be beneficial in alleviating chronic inflammation remaining in the periapical tissue. The anti-inflammatory property would also contribute to reducing excessive postoperative inflammation that can be induced through e.g., foreign body responses. Before clinical application, however, further studies are warranted on several other properties of S-PRG sealer, such as sealing ability, dimensional stability, and other physical properties.

\section{CONCLUSION}

S-PRG sealer extract downregulated the expression levels of proinflammatory cytokines including IL-1 $\alpha$, IL- 6 , and $\mathrm{TNF} \alpha$, as well as p-NF-kB expression; these effects may be mediated by $\mathrm{Zn}^{2+}$-dependent mechanisms. 


\section{ACKNOWLEDGMENTS}

This work was supported in part by a Grant-in-Aid for Scientific Research (Nos. 21K09870 to N.K. 19K24136, 20K18496 to S.N. 20K18499, 21K09911 to K.H.) from the Japan Society for the Promotion of Science. We thank Ryan Chastain-Gross, Ph.D., from Edanz Group (https:// jp.edanz.com/ac) for editing a draft of this manuscript.

\section{CONFLICTS OF INTEREST}

The authors declare no financial conflicts of interest related to this study.

\section{REFERENCES}

1) Johnson W, Kulild JC, Tay F. Obturation of the cleaned and shaped root canal system. In: Hargreaves, KM, Berman LH, editors. Cohen's pathways of the pulp. 11th ed. St. Louis: Elsevier; 2016. p. 280-322.

2) Ørstavik D. Endodontic filling materials. Endod Topics 2014; 31: 53-67.

3) Suresh Chandra B, Gopikrishna V. Obturation of the radicular space. In: Suresh Chandra B, Gopikrishna V, editors. Grossman's endodontic practice. 12th ed. New delhi: Wolters Kluwer; 2010. p. 278-307.

4) Komabayashi T, Colmenar D, Cvach N, Bhat A, Primus C, Imai Y. Comprehensive review of current endodontic sealers. Dent Mater J 2020; 39: 703-720.

5) Schäfer E, Zandbiglari T. Solubility of root-canal sealers in water and artificial saliva. Int Endod J 2003; 36: 660-669.

6) Lee BN, Hong JU, Kim SM, Jang JH, Chang HS, Hwang YC, et al. Anti-inflammatory and osteogenic effects of calcium silicate-based root canal sealers. J Endod 2019; 45: 73-78.

7) Jo SB, Kim HK, Lee HN, Kim YJ, Patel KD, Knowles JC, et $a l$. Physical properties and biofunctionalities of bioactive root canal sealers in vitro. Nanomaterials 2020; 10: 1-19.

8) Fujimoto Y, Iwasa M, Murayama R, Miyazaki M, Nagafuji A, Nakatsuka T. Detection of ions released from S-PRG fillers and their modulation effect. Dent Mater J 2010; 29: 392-397.

9) Ma S, Imazato S, Chen JH, Mayanagi G, Takahashi N, Ishimoto T, et al. Effects of a coating resin containing S-PRG filler to prevent demineralization of root surfaces. Dent Mater J 2012; 31: 909-915.

10) Kaga M, Kakuda S, Ida Y, Toshima H, Hashimoto M, Endo $\mathrm{K}$, et al. Inhibition of enamel demineralization by buffering effect of S-PRG filler-containing dental sealant. Eur J Oral Sci 2014; 122: 78-83.

11) Kaga N, Toshima H, Nagano-Takebe F, Hashimoto M, Nezu $\mathrm{T}$, Yokoyama A, et al. Inhibition of enamel demineralization by an ion-releasing tooth-coating material. Am J Dent 2019; 32: 27-30.

12) Miyauchi T. Remineralization of carious dentin with bioactive restorative materials. Jpn J Conserv Dent 2009; 52 : 469-482.

13) Saku S, Kotake H, Scougall-Vilchis RJ, Ohashi S, Hotta M, Horiuchi S, et al. Antibacterial activity of composite resin with glass-ionomer filler particles. Dent Mater J 2010; 29: 193-198.

14) Yassen GH, Huang R, Al-Zain A, Yoshida T, Gregory RL, Platt JA. Evaluation of selected properties of a new root repair cement containing surface pre-reacted glass ionomer fillers. Clin Oral Investig 2016; 20: 2139-2148.

15) Han L, Okiji T. Evaluation of the ions release/incorporation of the prototype S-PRG filler-containing endodontic sealer. Dent Mater J 2011; 30: 898-903.

16) Kawashima N, Hashimoto $K$, Kuramoto M, Bakhit A,
Wakabayashi Y, Okiji T. A novel bioactive endodontic sealer containing surface-reaction-type prereacted glass-ionomer filler induces osteoblast differentiation. Materials (Basel) 2020; 13: 4477.

17) Miyaji H, Mayumi K, Miyata S, Nishida E, Shitomi K, Hamamoto A, et al. Comparative biological assessments of endodontic root canal sealer containing surface pre-reacted glass-ionomer (S-PRG) filler or silica filler. Dent Mater J 2020; 39: 287-294.

18) Kawashima N, Okiji T, Kosaka T, Suda H. Kinetics of macrophages and lymphoid cells during the development of experimentally induced periapical lesions in rat molars: A quantitative immunohistochemical study. J Endod 1996; 22: 311-316.

19) Suzuki N, Okiji T, Suda H. Enhanced expression of activationassociated molecules on macrophages of heterogeneous populations in expanding periapical lesions in rat molars. Arch Oral Biol 1999; 44: 67-79.

20) Metzger Z. Macrophages in periapical lesions. Dent Traumatol 2000; $16: 1-8$

21) Kawashima N, Stashenko P. Expression of bone-resorptive and regulatory cytokines in murine periapical inflammation. Arch Oral Biol 1999; 44: 55-66.

22) Ralph P, Nakoinz I. Antibody-dependent killing of erythrocyte and tumor targets by macrophage-related cell lines: enhancement by PPD and LPS. J Immunol 1977; 119: 950-954.

23) Shumaker DK, Vann LR, Goldberg MW, Allen TD, Wilson KL. TPEN, a $\mathrm{Zn}^{2+} / \mathrm{Fe}^{2+}$ chelator with low affinity for $\mathrm{Ca}^{2+}$, inhibits lamin assembly, destabilizes nuclear architecture and may independently protect nuclei from apoptosis in vitro. Cell Calcium 1998; 23: 151-164.

24) Kawai T, Akira S. Signaling to NF- $\mathrm{kB}$ by Toll-like receptors. Trends Mol Med 2007; 13: 460-469.

25) Wahli W, Michalik L. PPARs at the crossroads of lipid signaling and inflammation. Trends Endocrinol Metab 2012; 23: 351-363.

26) Marx N, KehrleB, Kohlhammer K, GrübM, KoenigW, Hombach $\mathrm{V}$, et al. PPAR activators as antiinflammatory mediators in human T lymphocytes: Implications for atherosclerosis and transplantation-associated arteriosclerosis. Circ Res 2002; 90: 703-710.

27) Ip WKE, Hoshi N, Shouval DS, Snapper S, Medzhitov R. Anti-inflammatory effect of IL-10 mediated by metabolic reprogramming of macrophages. Science 2017; 356: 513-519.

28) Kashiwagi K, Inoue H, Komasa R, Hosoyama Y, Yamashita $\mathrm{K}$, Morisaki A, et al. Optimal dilutions of S-PRG filler eluate for experiments on human gingival fibroblasts in vitro. Dent Mater J 2021; 40: 136-142.

29) Schmid-Schwap M, Franz A, König F, Bristela M, Lucas T, Piehslinger E, et al. Cytotoxicity of four categories of dental cements. Dent Mater 2009; 25: 360-368.

30) Hong CY, Lin SK, Kok SH, Cheng SJ, Lee MS, Wang TM, et $a l$. The role of lipopolysaccharide in infectious bone resorption of periapical lesion. J Oral Pathol Med 2004; 33: 162-169.

31) Xiong B, Shirai K, Matsumoto K, Abiko Y, Furuichi Y. The potential of a surface pre-reacted glass root canal dressing for treating apical periodontitis in rats. Int Endod J 2021; 54: 255-267.

32) Scorei RI, Ciofrangeanu C, Ion R, Cimpean A, Galateanu B, Mitran V, et al. In vitro effects of calcium fructoborate upon production of inflammatory mediators by LPS-stimulated RAW 264.7 macrophages. Biol Trace Elem Res 2010; 135: 334-344.

33) Lee HJ, Choi CH. Anti-inflammatory effects of bamboo salt and sodium fluoride in human gingival fibroblasts - An in vitro study. Kaohsiung J Med Sci 2015; 31: 303-308.

34) Zhu S, Hu X, Tao Y, Ping Z, Wang L, Shi J, et al. Strontium inhibits titanium particle-induced osteoclast activation and 
chronic inflammation via suppression of NF-kB pathway. Sci Rep 2016; 6: 1-11.

35) Lee JH, Lee HH, Kim KN, Kim KM. Cytotoxicity and antiinflammatory effects of zinc ions and eugenol during setting of $\mathrm{ZOE}$ in immortalized human oral keratinocytes grown as three-dimensional spheroids. Dent Mater 2016; 32: e93e104.

36) Hyun HJ, Sohn JH, Ha DW, Ahn YH, Koh JY, Yoon YH. Depletion of intracellular zinc and copper with TPEN results in apoptosis of cultured human retinal pigment epithelial cells. Investig Ophthalmol Vis Sci 2001; 42: 460-465.

37) Matias AC, Manieri TM, Cerchiaro G. Zinc chelation mediates the lysosomal disruption without intracellular ROS generation. Oxid Med Cell Longev 2016; 2016: 1-14.

38) Brieger A, Rink L, Haase H. Differential regulation of TLRdependent MyD88 and TRIF signaling pathways by free zinc ions. J Immunol 2013; 191: 1808-1817.

39) Araki K, Suda H, Barbosa SV, Spångberg LS. Reduced cytotoxicity of a root canal sealer through eugenol substitution. J Endod 1993; 19: 554-557.

40) Kuramoto M, Kawashima N, Tazawa K, Nara K, Fujii M, Noda $\mathrm{S}$, et al. Mineral trioxide aggregate suppresses proinflammatory cytokine expression via the calcineurin/nuclear factor of activated $\mathrm{T}$ cells/early growth response 2 pathway in lipopolysaccharide-stimulated macrophages. Int Endod J 2020; 53: 1653-1665.

41) Nara K, Kawashima N, Noda S, Fujii M, Hashimoto K, Tazawa K, et al. Anti-inflammatory roles of microRNA 21 in lipopolysaccharide-stimulated human dental pulp cells. J Cell Physiol 2019; 234: 21331-21341.

42) Iotsova V, Caamaño J, Loy J, Yang Y, Lewin A, Bravo R.

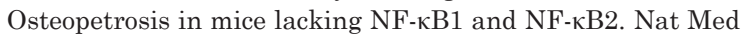

1997; 3: 1285-1289.

43) Boyce BF. Advances in osteoclast biology reveal potential new drug targets and new roles for osteoclasts Brendan. J Bone Min Res 2013; 28: 711-722.

44) Prasad AS, Bao B, Beck FWJ, Sarkar FH. Zinc-suppressed inflammatory cytokines by induction of A20-mediated inhibition of nuclear factor-кB. Nutrition 2011; 27: 816-823.

45) Golovine K, Uzzo RG, Makhov P, Crispen PL, Kunkle D, Kolenko VM. Depletion of intracellular zinc increases expression of tumorigenic cytokines VEGF, IL-6 and IL-8 in prostate cancer cells via NF-kB-dependent pathway. Prostate 2008; 68: 1443-1449.

46) Wessels I, Haase H, Engelhardt G, Rink L, Uciechowski P. Zinc deficiency induces production of the proinflammatory cytokines IL-1 $\beta$ and TNF $\alpha$ in promyeloid cells via epigenetic and redox-dependent mechanisms. J Nutr Biochem 2013; 24: 289-297.

47) Reiterer G, Toborek M, Hennig B. Peroxisome proliferator activated receptors $\alpha$ and $\gamma$ require zinc for their antiinflammatory properties in porcine vascular endothelial cells. J Nutr 2004; 134: 1711-1715.

48) Clarke SD, Thuillier P, Baillie RA, Sha X. Peroxisome proliferator-activated receptors: A family of lipid-activated transcription factors. Am J Clin Nutr 1999; 70: 566-571.

49) Bao B, Prasad AS, Beck FWJ, Fitzgerald JT, Snell D, Bao GW, et al. Zinc decreases C-reactive protein, lipid peroxidation, and inflammatory cytokines in elderly subjects: A potential implication of zinc as an atheroprotective agent. Am J Clin Nutr 2010; 91: 1634-1641.

50) Sasaki H, Hou L, Belani A, Wang CY, Uchiyama T, Müller $\mathrm{R}$, et al. IL-10, but not IL-4, suppresses infection-stimulated bone resorption in vivo. J Immunol 2000; 165: 3626-3630. 